\title{
Transznacionális Irán \\ Nem állami szereplők a Közel-Keleten - militáns partnerek Teherán „szolgálatában”
}

\author{
Transnational Iran \\ Non-State Actors in the Middle East - \\ Militant Partners at Tehran's "Service"
}

Ablaka Gergely

https://doi.org/10.47707/Kulugyi_Szemle.2021.3.4

„A határainkon kiviul is komoly képességekkel rendelkezünk. Vannak támogatóink az egyes orszagokban, van stratégiai mélységünk az egész régióban. Vannak, akik az iszlám vallás, mások a nyeh, megint mások a siita kötelék miatl támogalnak minket. Ezek egyült az országunk stratégiai mélységét alkotják."

Ali Khamenei (Rasa News, 2015)

Összefoglaló: A világon talán nincs még egy olyan állam, amely annyira sikeresen használná ki a nem állami aktorokban rejlő lehetőségeket, mint az Iráni Iszlám Köztársaság. A teheráni vezetés a történelmi kapcsolatrendszerének, a stratégiai türelmének, a forradalmi-ideológiai célkitűzéseinek és a vallási-kulturális kötelékeinek köszönhetően rendkívül széles és színes hálózatot hozott létre maga körüil, amelynek a határokon átívelő militáns „alkotóelemei” nagyon komoly befolyást biztosítanak számára a hadszíntereken, illetve az iráni atomprogramnál és rakétaarzenálnál is nagyobb „elrettentő erőt” nyújtanak a rezsim ellenségeivel szemben. A nem állami szereplők azonban nemcsak Irán „eszközei”: a Közel-Kelet bóvelkedik ezekben az aktorokban, amelyek a kialakulásuk és a fennmaradásuk okait, a múködésük biztonsági következ ményeit illetően különböznek ugyan, de a létezésüik kontextusát a problémás államiság és a regionális hatalmi versengés nyújtja. A fegyveres nem állami szereplőkre támaszkodó iráni taktika ebben a környezetben, az ország biztonsági gondolkodása, a politikai, társadalmi, kulturális és gazdasági adottságai tükrében alakult. Az ún. „ellenállás tengelye” az iráni stratégiai érdekek és a nem állami viszonyok összetettségének az eredménye, amelyben kiemelt szerepet játszik a libanoni Hezbollah. 
Kulcsszavak: Irán, fegyveres nem állami szereplők, Hezbollah, erőszak, Qudsz Erők, „az ellenállás tengelye”

Abstract: There is perhaps no other state in the world that is as successful in exploiting the potential of non-state actors as the Islamic Republic of Iran. Thanks to its historical system of relations, strategic patience, revolutionaryideological goals and religious-cultural ties, the Tehran leadership has created an extremely wide and colourful network around ilself, whose cross-border militant "components" give it a very serious influence on the batllefields, and they also provide even a greater "deterrent force" against the regime's enemies than Iranis nuclear program and missile arsenal. However, non-state actors are not only Iran's "assets:" the Middle East abounds in these actors, which differ in the reasons for their formation and survival, the security consequences of their operation, but the context of their existence is the problematic statehood and the regional power compelition. Iran's lactics, relying on armed non-state actors, have evolved in this environment, in the light of the country's security thinking, political, social, cultural and economic capabilities. The so-called the axis of resistance" is the result of the complexily of Iran's strategic interests and non state relations, in which Lebanese Hezbollah plays a key role.

Keywords: Iran, militant non-state actors, Hezbollah, violence, Quds Force, the axis of resislance"

\section{Nem állami szereplók a Közel-Keleten}

A „fegyveres nem állami szereplők” kifejezés igen összetett fogalmat takar: küiönböző nézőpontok mentén több definíciós lehetőség is kínálkozik rá (Aydinli, 2015, 424-444. o.). Leegyszerúsítve ezek a szerveződések olyan fegyveres csoportok, amelyek a politikai céljaik elérése érdekében az államokon kívül múködve képesek az erőszak sikeres alkalmazására. A közös jellemvonásaik között (Ali, 2020, 71-73. o.) először is a szervezettségüket emlithetjüik: saját névvel, szervezeti felépitéssel, toborzási mintával, vezetési stílussal, döntési dinamikával rendelkeznek. Másodszor, e csoportok az állami intézményeken, a hivatalos védelmi-biztonsági szerveken kívül múködnek, veszik át az ellenőrzést a földrajzi területek és egyes társadalmi csoportok felett, 


\section{Külïgyi Szemle}

adott esetben pedig az állam feladatait is gyakorolják. Harmadszor, a politikai, gazdasági, társadalmi céljaik megvalósítása érdekében szisz tematikus erőszakot alkalmaznak, amely a természetét tekintve irre guláris és nem konvencionális - sokszor brutális. Azonban az „alaku latok" összetartásához, az erőszak igazolásához, illetve a megszerzett autoritás társadalmi legitimálásához szüikség van bizonyos „hitrendszerekre", értékekre, normákra és ideológiákra, amelyek konstruálhat ják, fenntarthatják és mozgósíthatják a helyi identitásokat - azaz biz tosíthatják a morális és materiális támogatásokat (Yeşiltaş és Kardaş, 2018, 3-6. o.). Negyedszer, bizonyos mértékú múködési és pénzügyi autonómiával rendelkeznek, emellett igyekeznek a nemzetközi közön séget mozgósítani és szövetségeket alkotni, ezáltal elismerést, támo gatást és védelmezést garantáló küllföldi partnereket szerezni. A ha tárokon átívelő vallási, etnikai, törzsi kapcsolatok következményeként és a szüikséges hadianyag-utánpótlás megszervezésének eredménye ként bizonyos belső vagy külső állami kötődéssel is rendelkeznek (Ali, 2020, 71. o.).

A fegyveres nem állami szereplők azonban a közös „definíciós” alapjegyek ellenére rendkívüil sokféle formában múködnek. Különböz hetnek egymástól az identitás, az ideológia, a cél, a stratégia, a taktika, a területi gondolkodás, a szervezeti felépítés, a döntéshozatal, a parancsnoklás, az emberi és anyagi utánpótlás, illetve a külső kapcsola tok tekintetében is (Zohar, 2016, 423-450. o.). Bizonyos szervezeteket a vallási és ideológiai kötelék, másokat az etnikai és törzsi származás fogja össze (lásd pl. a síita népi milíciákat és a kurd paramilitáris erőket). Egyes szereplők a lokális (belpolitikai) folyamatok befolyásolására törekednek, mások inkább a regionális/globális (nemzetközi) színtéren próbálnak megjelenni (pl. a palesztin Hamász „odahaza” tevékenykedik, míg az Iszlám Állam határokon átívelő hálózatba szerveződik). Vannak olyan csoportosulások, amelyek a központi kormányzat, a regnáló vezetés megdöntéséért küizdenek (lásd a húszi mozgalomnak a Hádi-kormányzattal szembeni küzdelmét Jemenben), míg a többiek az állami intézményekkel együttműködve igyekeznek fenntartani a hatalmi berendezkedést (pl. az Aszad-rezsimet támogató milíciák 
Szíriában). Némelyek decentralizáltan működnek, a többségben viszont hierarchia érvényesüil (lásd pl. az al-Káida hálózatát, illetve a kurdok szervezettségét). Egyesek önerőre támaszkodnak, mások erősen függenek a külső támogatóiktól (az elóbbire a Hezbollah, az utóbbira a Nuszra Front lehet jó példa). E militáns szerveződések a katonai képességeik, a pénzügyi lehetőségeik, a harctéri tapasztalataik, a technológiai eszközeik, valamint a társadalmi beágyazottságuk tekintetében is eltérhetnek egymástól (Yeşiltaş és Kardaş, 2018, 6-10.o.).

A Közel-Keleten a sok-sok szempontot és szereplőt figyelembe véve a fegyveres nem állami szereplők négy fő modelljét lehet megküiönböztetni - a kategóriák között természetesen lehetnek átfedések, egyes csoportok (pl. az Iszlám Állam) több típusnak is megfelelhetnek (Ali, 2020, 73-78. o.). A „hibrid szervezetek” többféle állami feladatkörrel és karakterjeggyel rendelkeznek, és nemcsak fegyveres küzdelmet folytatnak, hanem adminisztratív gépezeteket, politikai mozgalmakat, gazdasági vállalkozásokat és vallási alapítványokat is múködtetnek, azaz fontos és összetett entitásokként vannak jelen a hétköznapokban (pl. a libanoni Hezbollah vagy a palesztin Hamász). Az „iszlamista-dzsihadista” mozgalmak, amelyek igen elterjedtek és komoly történelmi múltra tekintenek vissza, a vallási ideológia (szalafita nézetek) mentén szerveződnek, s lehetnek az adott állam határain belül tevékenykedô csoportok (pl. a Nuszra Front Szíriában) vagy igazi nemzetközi hálózatok (pl. az al-Káida „leányvállalatai” a Közel-Keleten és Észak-Afrikában). A fegyveres és a paramilitáris csoportok alapvetően adott területekre (pl. fontos nyersanyaglelőhelyek és infrastrukturális létesítmények megszerzésére, illetve a független államiság területi hátországának a kiépítésére) összpontosítanak. Végüil, de nem utolsósorban, a vallási, etnikai és törzsi milíciák az állami keretek meggyengüilésével, a helyi identitások felerősödésével (a tár sadalmi viszonyok és jellemzők figyelembevételével) játszanak fontos szerepet az egyes hadszíntereken - lásd a törzsi struktúra jelentősé gét Líbiában és Jemenben (Adebahr, Berti, Eljarh és Kausch, 2016).

A közel-keleti fegyveres nem állami szereplők "története” meszszire és mélyre nyúlik vissza, a megjelenésük és a megerősödésük 


\section{Külïgyi Szemle}

számtalan faktor és folyamat eredménye. Először is, mivel a közel-ke leti és észak-afrikai régió társadalmilag nagyon összetett, a népesség az etnikai, vallási, törzsi és ideológiai törésvonalak mentén rendkívül tagolt; a komplex identitások miatt a gyakorlatban minden tágabb közösségépítő kísérlet csak nehézkesen valósítható meg. A területiségen alapuló vesztfáliai modell a Közel-Kelet politikai fejlődésétől idegen, hiszen ott mindig a helyi szolidaritások és a többnemzetiségú biro dalmak játszottak meghatározó szerepet, és a modern állami keretek kívülről kikényszerített fejlődés, mesterséges meghatározás, valamint szúk körű politikai megállapodás következményeként jöttek létre ezért mind a mai napig nagyon sérülékenyek, és nem feltétlenül fedik le a vesztfáliai állam funkcióit (N. Rózsa, 2018, 16-34. o.).

Másodszor, a függetlenség megszerzését követően olyan diktatórikus rendszerek alakultak ki, amelyek nem képviselték a társadalom többségét - épp ellenkezőleg: szélesebb rétegeket zártak ki a döntések alakításából, így a mozgalmi korszakot követően számos esetben zártabb rezsimek jöttek létre. Az elnyomó intézkedések nem csupán a rendszerek legitimitását ásták alá, hanem folyamatosan kitermelték a rezsimellenes szereplőket, és megerősítették a központi kormányzattal szembeni (szeparatista) törekvéseket is (Polese és Santini, 2018, 379-390. o.). A diktatúrák természetének és működésének hozadékaként meghatározó lett a nepotizmus, a mindent átható korrupció, a korántsem hatékony, ám túlburjánzó bürokrácia, valamint a rosszul meghozott/végrehajtott szakpolitikai döntések - e hibák és hiányos ságok pedig a hivatalos állami struktúrák kiüresedéséhez és a speciális félállami entitások megszerveződéséhez vezettek. Mindezt számos strukturális hiba is erősítette, így például a territorialitás kérdésének a megválaszolatlansága vagy éppen a posztkoloniális államstruktúra és gazdaságszerkezet érintetlenüil hagyása (Sluglett és Kattan, 2019, 2-6. o.).

Harmadszor, a „külvilágnak” is roppant fontos szerepe volt a fegyve res nem állami szereplők létrejöttében. Érdemes megemlíteni többek közt az amerikai-szovjet hidegháborús versengést - amely lényegében lehetőséget és támogatást biztosított az állammal szemben harcoló 
csoportok megszületéséhez -, illetve a késóbbi amerikai katonai in tervenciókat (rezsimváltásokat), amelyek egyfajta kiindulási alapot te remtettek a különféle lázadó csoportok megszerveződéséhez (lásd pl. a Szaddám Huszein utáni iraki helyzetet).

Ugyanígy figyelembe kell venni a regionális kontextust is, a Közel Kelet anarchikus természetét, a szereplők közti folyamatos hatalmi versengést, a térség átformálására irányuló törekvést, amelyben lé nyeges szerepe van az állami szint alatti csoportosulások segélyezé sének - hiszen a szemben álló felek a közvetlen konfrontáció elkerüilé se érdekében alapvetően helyettesekkel folytatott, nem hagyományos háborút vívtak/vívnak (Kausch, 2017, 36-47. o.).

Az „arab tavasz” óta eltelt tíz évben megsokszorozódott a fegyveres nem állami szerveződések száma a Közel-Keleten és Észak-Afrikában, ami tulajdonképpen az állami keretek/képességek meggyengülésével, a polgárháborúk kirobbanásával és elmélyülésével, az új típusú autoriter vezetési technikák megjelenésével, a regionális hatalmi versengés intenzitásának az erősödésével, valamint a taktikai és technológiai fejlődéssel függ össze (Yeşiltaş és Kardaş, 2018, 10-14. o.). Az arab forradalmakat követően több országban is összeomlott a kormányzat, illetve komolyan sérült a központi autoritás (egyfajta „államvákuum” alakult ki), az egyre véresebb belharcok és a mind határozottabbá vált „állam alatti” identitások pedig ideális terepet teremtettek a fegyveres nem állami szereplők felemelkedéséhez (Durac, 2015, 37-41. o.).

Ezt a folyamatot tovább erôsítette, hogy egyes állami vezetések a strukturális gyengeségeik, politikai lehetőségeik, illetve stratégiai előnyeik felmérése után igyekeztek kooptálni a nem állami szerve ződéseket - így például a területek feletti ellenőrzés megtartása vagy a politikai ellenzék félreállítása érdekében a védelmi és rezsimbiz tonsági feladatköröket a különféle fegyveres csoportoknak adták át, vagy éppen azokat vonták be az állami fegyveres erők kötelékébe. Ez zel egyfajta „hibrid partnerség” formálódott (Szalai, 2020, 67-71. o.). Mindemellett az elmúlt évtizedben zajlott szaúdi-iráni „hidegháborús" rivalizálás során jelentősen felerősödött rijádi és teheráni vezetés egyaránt a közvetlen konfrontáció elkerülésére, ugyanakkor minden 


\section{Külïgyi Szemle}

fontosabb hadszíntéren aktívabb megjelenésre, az ellenlábasa gyengí tésére és az érdekei érvényesítésére törekszik, ezáltal tulajdonképpen biztos szponzorként garantálják a fegyveres nem állami partnerek to vábbi működését, s így egyfajta „funkcionális kapcsolódás” jött létre (Santini, 2017, 101-107. o.).

A regionális vizsgálódásnál számításba kell venni a globális hatalmi rivalizálást is, így például az orosz-amerikai szembenállás kiújulását (pl. a szíriai polgárháború kapcsán) vagy az amerikai-kínai versengés megjelenését (pl. a Perzsa-öböl térségében). A nem állami szereplők megerősödése kapcsán a gazdasági tényezőket sem lehet figyelmen kívül hagyni: az államok szétesésével egyes fegyveres aktorok szereztek ellenőrzést a stratégiai nyersanyagforrásokban gazdag területek felett, ami pénzügyi stabilitást, szervezettséget, fenntarthatóságot eredményezett (pl. a líbiai konfliktusban). Végül, de nem utolsósorban, meg lehet említeni a taktikai változtatásokat és a technológiai újításokat is, így például az aszimmetrikus képességeknek a modern hadviselésben való jelentőségét, valamint a kommunikációs-információs eszközöknek az identitáskötelékek megszervezésében betöltött szerepét.

A fegyveres nem állami szereplők tehát lokális, regionális és glo bális szinten egyaránt komoly kihívásokat generálnak (Sluglett és Kattan, 2019, 1-2. o.): gyengítik a közel-keleti állami struktúrákat, támadják vagy éppen „függőségbe” kényszerítik a kormányzatokat, az erőszakos küzdelmükkel még jobban kiélezik a társadalmi törésvonalakat, az etnikai és vallási ellentéteket, az erőforrások lekötésével pedig mélyítik a gazdasági-pénzügyi válságokat is. Lényegében újratermelik a polgárháborús helyzeteket, a problémás állami intézményeket, az igazságtalan társadalmi szerkezeteket, s mindemellett számtalan súlyos humanitárius és környezeti kihívást teremtenek. A regionális biztonsági komplexum dinamikáját is befolyásolják, amennyiben szövetségi hálózatokat építve és határon túli szerepeket vállalva alakítják (vagy felborítják) az érzékeny hatalmi egyensúlyt (Arany, N. Rózsa és Szalai, 2016, 139-164. o.). A szaúdi-iráni hidegháborúban formálódó szövetségek alapját a fegyveres nem állami szereplők alkotják, amelyek 
nemcsak „proxykként” vannak jelen a konfliktusokban, hanem sokkal inkább egyfajta koalícióformálókként vesznek részt a folyamatokban (ez a regionális hatalmi versengés tulajdonképpen alul ról szerveződik) (Gause, 2014, 8-12. o.). A globalizációs folyamat és a kommunikációs forradalom „sötét oldalának” a kihasználásával ráadásul képesek távolabbi „sofl” célpontok támadására, elszánt követők és támogatók toborzására, illetve („újfajta”) terrorista cselekmények inspirálására is - a Füiöp-szigetektől Franciaországig (Yeşiltaş és Kardaş, 2018, 4. o.).

A fegyveres nem állami szereplők nemcsak számos fenyegetést jelentenek, hanem komoly fejtörést is okoznak, mivel nehéz őket kezelni - felszámolni vagy éppen integrálni (Ali, 2020, 79-80. o.). Az al Káida és az Iszlám Állam példája jól szemlélteti, hogy katonailag meg lehet törni ugyan, de politikailag és társadalmilag nagyon nehéz viszszaszorítani ezeket a szerveződéseket (és gondolkodásokat), különö sen, hogy az „arab tavaszt” kiváltó és az amerikai intervenciókat övező problémákat továbbra sem sikerült kellőképpen orvosolni. A jelentős társadalmi egyenlőtlenségek és igazságtalanságok, illetve az állami és intézményi gyengeségek megfelelő táptalajt biztosítanak a küilönféle radikális mozgalmaknak.

A militáns nem állami csoportoknak a hivatalos intézményrend szerbe történő beemelése sem tűnik egyszerű feladatnak, hiszen a különleges pozícióik és relációik következtében a védelmi struktúrák ba illeszkedve is megőrizhetik a működési-szerveződési függetlenségüket, ráadásul az etnikai vagy vallási alapon szerveződó fegyveres milíciák integrációja a kulturális feszültségeket átemelheti a nemzeti hadseregekbe is (lásd pl. Irak vagy Afganisztán esetét). A velüik való együttélés küilönösen nehéz az adott állam számára, hiszen e fegyveres egységek az erőszak-monopóliumuk birtokában küiönleges és rendkívül előnyös pozícióban vannak a belpolitikai ellenfeleikkel szemben, továbbá az állami külpolitikától eltérő (annak ellentmondó) akciókat is végre tudnak hajtani (a libanoni politikai krízis például tulajdonképpen a mai napig a Hezbollah be nem szolgáltatott fegyvereiről szól) (Khatib, 2021, 3-5. o.). 


\section{Külïgyi Szemle}

Összességében kijelenthető, hogy a fegyveres nem állami sze replők megkerülhetetlen játékosok a közel-keleti folyamatokban, erő szakos akcióikkal, funkcionális szervezettségükkel, a földrajzi terület ellenőrzésével, valamint a külföldi kapcsolataikkal rendkívüil izgalmas és roppant befolyásos aktoroknak számítanak a szúkebb és tágabb erőtérben. A társadalmi jellemzők, az intézményi gyengeségek, a kontextuális kihívások, továbbá a geopolitikai versengések mind-mind arra utalnak, hogy hosszabb távon is számolni kell e szerveződéseknek a regionális dinamikát alakító szerepével. Tulajdonképpen egyfaj ta „hibridizáció” figyelhető meg a közel-keleti térségben: a hagyomá nyos állami és a fegyveres nem állami szereplők egymással versengve, ugyanakkor együittmúködve alakítják a régió biztonsági, politikai és társadalmi folyamatait.

\section{Nem állami szereplók az Iráni Iszlám Köztársaság stratégiájában}

Az Iráni Iszlám Köztársaság biztonsági stratégiájában kulcsszerepe van a küilönféle nem állami szereplőkkel kiépített kapcsolatrendszernek. Ez egyrészt a közel-keleti játéktér fő jellemzőivel, a régió konfliktusosságával (a vákuumhelyzetekkel) van összefüggésben, másrészt viszont számos politikai tényezô és történelmi folyamat eredménye: a földrajzi adottságok, a gazdasági képességek, a társadalmi jellemzők, a transznacionális kulturális kötelékek, a forradalmi elvek, a síita vallási narratívák, a regionális hatalmi ambíciók, a területvédelmi megfontolások, a nem hagyományos taktikák, valamint a korlátozott államközi viszonyok mind-mind fontos szerepet játszanak e nem állami kapcsolatok kiépítésében és működtetésében.

Irán történetében a nem állami szereplőkkel való együttműkö dés, a fegyveres milíciákra és a lázadó csapatokra való támaszko dás nem új keletű jelenség. E hagyomány egészen az 1950-es évekig vezethető vissza: Mohamed Reza Pahlavi sah „birodalmi Iránjában” az extraterritoriális aktorok lényeges szerepet játszottak az érzékelt fenyegetések ellensúlyozásában, illetve a térségbeli ellenfelek meggyengítésében (a Pahlavi-dinasztia regionális hatalmi ambícióit 
az Amerikai Egyesült Államok határozottan támogatta). Az uralkodó a fegyveres nem állami csoportokat pénzzel, fegyverrel és kiképzés sel támogatta, adott esetben a vallási kötődéseket is kihasználta, és így akarta megakadályozni a baloldali és/vagy arab nasszerista erők nemzetközi térnyerését (ún. „zöld terv”), illetve a kurdok küilönféle szerveződéseinek a felkarolásával igyekezett ellehetetleníteni bagdadi ellenlábasát a terüileti-hatalmi viták feloldása során (Ataie, 2021, 1-7. o.). A sah idején Iránnak fontos szerepe volt a Szovjetunió feltartóztatásában, az antikommunista fegyveres csoportok segélyezésében is.

A nem állami szereplők jelenléte az 1979-es forradalom (és az azt követő iraki-iráni háború) kapesán is megfigyelhető volt: a vallási elitből sokan palesztin kiképzőtáborokban kaptak katonai felkészítést, illetve szereztek harci tapasztalatokat és kötöttek hosszú távú ideológiai barátságokat (a forradalmi elit több tagja Libanonban lelt menedékre a sah titkosrendőrsége elől, ahol már a polgárháború kirobbanása előtt fontos politikai szerepet vállaltak, és részt vettek az elnyomott síita kisebbség megszervezésében). A nem állami szereplők és az informális kötelékeik az iszlám forradalom győzelmét követően kialakított politikai-hatalmi berendezkedésben is komoly szerephez jutottak. Számtalan „félállami segédstruktúrát” hoztak létre - többek között a Forradalmi Gárda speciális egységét, a Qudsz Eróket -, amelyekkel a hivatalos állami struktúrák mellett (egyfajta párhuzamos küilpolitikát folytatva) a nem állami kapcsolatokat kívánták alakítani, valamint a lázadó fegyveres csoportok támogatását menedzselni, tulajdonképpen a „forradalom exportálását” biztosító ellenzéki mozgalmakat (pl. a Szaddám Huszein uralmával szemben álló síita csoportok militáns szárnyait) megszervezni (Riazaty, 2016, 226-231. o.). Ez a csapat ma is jelen van a főbb - Iránon kívuili - hadszíntereken, kiképzi és felfegyverzi a helyi eróket, adott esetben pedig a parancsnokai köz vetlenüil irányítják a hadmúveleteket (Esfandiari, 2020).

Az Iráni Iszlám Köztársaság ugyanazon okokból használja e nem állami játékosokat, mint az előző rendszer tette: a rezsimbiztonsági megfontolások mellett elsősorban a regionális erótérben akar pozíciókat szerezni, illetve azokat megtartani és tovább bővíteni. 


\section{Külïgyi Szemle}

A forradalom eredményeként két új elem segítette és erősítette ezt a transznacionális hálózatépítő stratégiát. Egyrészt a síita iszlám, amely egyfajta keretrendszert teremtett a kapcsolatépítéshez: Tehe rán a vallási elveket, emóciókat, jelképeket, történeteket és tanításokat felhasználásával képes legitimálni a nemzetközi lépéseit, mozgósítani a szövetségeseit, valamint megbízható és elkötelezett harcosokat verbuválni, nem utolsósorban pedig közös narratívát (stratégiai célokat és biztonsági fenyegetéseket) alkotni, ami összefogja és egyben tartja e nem állami kötelékeket (Soltaninejad, 2019, 721-727. o.). Igy például Irán a „síita univerzum” közepének tekinti magát, és arra hivatkozva avatkozik be Szíriában; a Szajjida Zeinab meeset, a damaszkuszi „szent” sír megvédésének hívószavával mobilizálja a partnereit; és az idegen megszálló erők elleni fegyveres küzdelem jegyében toboroz síita zsoldos sereget (Ahmadian és Mohseni, 2019, 344-348. o.). Tehe rán a nem állami relációk megszervezésekor a síita ellenzékiség több évszázados szellemi (és érzelmi) hagyományára építhet, illetve a múlt század végén köttetett praktikus ellenzéki kooperációkat is felhasználhatja (lásd pl. a Szaddám-ellenes kötelékeket Irakban) (Bajoghli, 2019). Meg kell jegyezni, hogy az 1979-es „iszlám” forradalomban Ruholláh Khomeini ajatollah igyekezett túllépni a „szektás” jellegen, megpróbálta szélesebb körben inspirálni és szervezni a különféle iszlám mozgalmakat.

Másrészt az új forradalmi világnézet elősegítette a nem állami relációk kiépítését, a forradalmi Irán a „se nem Kelet, se nem Nyugat” külpolitikájával (a hidegháborús kontextusban) az igazságtalan világrendet kérdőjelezte meg, kötelezettségként határozta meg az „elnyo mottak" (palesztinok) megsegítését, az új rezsim kezdettől fogva igye kezett minden szabadságharcos mozgalmat felkarolni, a felforgató te vékenységüket bőkezúen szponzorálni (Posch, 2013, 14-17. o.). A síita vallási elvek és az egyfajta forradalmi világrend-ellenességen alapuló ideológiai célkitűzések kombinálásával az Iráni Iszlám Köztársaság olyan „kötőanyagra” tett szert, amellyel lehetősége nyílt a forradalom valódi „exportálására”, a határokon és nációkon átívelő, szerteágazó és időtálló nem állami viszonyrendszerek létrehozására és működtetésére (Katz, 2018). 
A fegyveres nem állami szereplőkkel való együttmúködés a politikai és a vallási elvek mellett jól illeszkedik a biztonsági megfontolásokhoz, így a stratégiai koncepcióban megfogalmazott „aktív elrettentés hez" (regionális erókivetítéshez) is. Egyrészt Irán igyekszik szélesebb hálózatot kialakítani, amelyre támaszkodva „proxyháborúkat” vívhat a közel-keleti ütközőzónákban, s ezáltal egyfajta preventív lépésként, „előretolt védelemként” távol tarthatja a konfliktusokat és az ellenségeit a határaitól. Ahogyan a forradalmi vezetésben mondják: „Most a biztonságunk szempontjából Szíria sokkal fontosabb, mint az olajban gazdag déli Khuzesztán tartományunk." (Ostovar, 2019, 176-177. o.) Másrészt Teherán olyan stratégiai mélység kialakítására törekszik, amely nem csupán a szárazföldi összeköttetést biztosítja Irán és az egyes proxyháborús területek között, de alkalmas lehet az ellenséges erők elleni offenzív hadmúveletekre is (pl. a szíriai területekről nemcsak Libanon könnyen elérhető, hanem közvetlenül Izraelre is csapást lehet mérni) (Behravesh, 2020, 5-9. o.). Végezetül, Teherán hosszabb távon egyfajta „iráni Monroe-elvet” hirdet: a regionális pozíciók-relációk megerősítésével próbálja folyamatosan az USA tudtára adni, hogy nincs szükség annak katonai erejére a Perzsa-öböl térségében (lásd pl. az iraki fegyveres milíciáknak az amerikai érdekeltségek ellen végrehajtott akcióit), hanem a regionális hatalmi szereplőknek kell alakítaniuk a helyi biztonsági folyamatokat (ezzel egyuitt a regionális hatalmiságra irányuló törekvéseit is kifejezi). Egyúttal elutasítja a washingtoni demokratizációs törekvéseket, a politikai számonkéréseket, amelyeket az iszlám köztársasági rendszerre nézve biztonsági fenyegetésnek tekint (félelem a „bársonyos forradalomtól”) (Gardner, 2019).

A nem állami viszonyrendszer tökéletesen alkalmas az aszim metrikus hadviselésre, a jól kalibrált erőszak-alkalmazásra, a stratégiai kifárasztásra vagy éppen a pszichológiai megfélemlítésre. Ugyanakkor Irán közel 200 éve nem indított háborút, és Teherán a nyílt konfliktusokat most is nagyon el akarja kerülni - az Iráni Iszlám Köztársaság érdekeinek sokkal inkább megfelel ez a fajta „távolsági” harcmodor. Habár a nemzetközi és az egyoldalú amerikai szankciók miatt (Csicsmann, 2021) Iránnak továbbra is viszonylag korlátozott a diplomáciai mozgástere, szúk az államközi kapcsolatrendszere, a nem 


\section{Külïgyi Szemle}

állami kötelékeinek köszönhetően azonban a térség szinte valamennyi fontosabb konfliktusában és kérdésében számolni kell vele, ami jól mutatja a regionális pozícióját és a Nyugattól való függetlenségét is.

Teherán olvasatában az erőszakos nem állami szerveződésekkel való együttmûködés számos további praktikus elônnyel is jár. Először is, általuk ellensúlyozni tudja a gyenge hagyományos katonai képes ségeit és az anyagi-pénzügyi hiányosságait. A már meglévő és műkö dő helyi erőkre való támaszkodás (azaz, hogy nem kell új szervezetet alapítani), a csupán korlátozott jelenlét szüiksége, a biztonsági és a védelmi feladatok kiszervezése igencsak olcsó megoldás (alacsony a „tranzakciós költség”), mindemellett kellőképpen hatékony taktikai lépés is (nem kell nagy eróket lekötni, a kisebb egységeket pedig sokkal könnyebb átvezényelni). Ráadásul a kiképzésre, felszerelésre, illetve stratégiai tanácsadásra szorítkozva fenntarthatóbb együttműködést lehet kiépíteni, a decentralizált megközelítés a helyi szereplők társadalmi támogatottságát és azok együttműködési készségét erősíti, így hosszabb távú jelenlétet teremthet (Clausen, 2020, 1-2. o.).

Másodszor, a különböző militáns csoportok felhasználásával úgy képes az ellenlábasait (közvetetten) gyengíteni-támadni, hogy maga a kellő távolságot megőrzi, így a saját felelősségét el tudja homályosítani, s a közvetlen konfrontációt elkerülni - erre jó példát jelentenek a húszi lázadók akciói Jemenben, illetve az olajfinomító ipari létesítmény elleni rakétatámadás Szaúd-Arábiában (Kirkpatrick, 2019). Harmadszor, e nem állami szerveződések alkalmazásával nemcsak az érintettségét tagadhatja, de csökkentheti a külföldi kalandozások kellemetlen belpolitikai (társadalmi és gazdasági) hatásait is (lásd az afganisztáni-pakisztáni zsoldosoknak a veszteségek minimalizálása érdekében történő bevetését az egyes hadszíntereken) (Majidyar, 2017).

Végül, mindent egybevetve (és az utóbbi háborús évek bizonyitékai alapján), e nem állami partnerek komoly harctéri tapasztalattal bírnak a kihívásokkal teli hegyvidéki, sivatagi és városi hadviselés ben. Ráadásul a közös stratégiai célok elérése érdekében a határo kon átívelően is jól együtt tudnak múködni, képesek az expedíciós erőikkel a közel-keleti konfliktusokban megjelenni és egymással 
vállvetve harcolni - lásd az iraki Aszá 'ib Ahl al-Haqqnak a libanoni Hezbollahhoz történt csatlakozását annak az Izrael ellen folytatott harcában (Katz, 2018, 1-8. o.).

Mindezek a nem állami csoportokban rejlő lehetőségek a korábbi aknál sokkal magabiztosabb, offenzivabb és rugalmasabb iráni pozí ciót tesznek lehetővé.

A militáns nem állami szereplókre támaszkodó taktika komoly eredményekkel kecsegtet, és Irán „nyerésre áll” számos hadszíntéren, ugyanakkor nem lehet figyelmen kívül hagyni azokat a problémákatfenyegetéseket sem, amelyekkel ez a harcmodor hosszabb távon jár hat. Az eltúlzott regionális szerepvállalás még inkább megerősítheti azt a washingtoni percepciót, hogy Teheránt nyomás alatt kell tartani, mindez pedig széles körú szankcionálást, kiterjedt hírszerzési megfigyelést és adott esetben célzott katonai fellépést válthat ki - pl. a Szolejmáni-gyilkosság határozott válaszlépés volt az iraki milíciáknak az amerikai célpontok elleni akcióira (Ward, 2020). A milíciák összefogásához és a hadmúveletek irányításához azonban professzionális vezetőre van szüikség, ezért a Qudsz Erők parancsnokának elvesztése hatalmas érvágás a teheráni rezsimnek (Middle East Institute, 2020).

Ugyanakkor az Irán által kialakított militáns nem állami hálózat és aszimmetrikus katonai fenyegetés képes a törésvonalakon átívelő szövetségeket is létrehozni - erre nagyon jó példa az öbölmonarchiáknak és Izraelnek az elmúlt időszakban tapasztalt stratégiai közeledése (Abadi, 2019, 433-449. o.). Azt is látni kell ugyanakkor, hogy ezek a militáns kapcsolatok megterhelik a szomszédos államokkal ápolt viszonyokat, és sokat rontanak az Iszlám Köztársaságról alkotott vélekedéseken. Ezt mutatja, hogy a 2019 őszén Irakban kibontakozott tüntetéseken a már a Szaddám utáni időszakban szocializálódott, fi atal dél-iraki síiták a mindent uraló, korrupt iráni befolyással szemben emelték fel a szavukat - azaz lényegében az etnikai identitáselem fogalmazódott meg a vallásival szemben (Rubin, 2019). Továbbá az Irán által támogatott helyi fegyveres milíciák önálló akciói (személyes törekvései) eszkalációhoz, nyílt konfliktushoz vezethetnek más, esetleg éppen ellenséges államokkal. Bár Teherán az ilyen kényelmetlen 


\section{Külïgyi Szemle}

esetektől ügyesen el tud határolódni, de még így is számolnia kell a következményekkel (lásd pl. a jemeni akciókat követő büntetőintézke déseket) (Borger és Smith, 2017). Akár nyer, akár veszít az egyes harc mezőkön, Iránnak mindenképpen bizonytalansággal kell szembenéz nie az adott országokban; a milíciákkal sikeresen lehet harcolni, területeket elfoglalni, azonban a politikában és a gazdaságban hatékonyan részt venni már korántsem olyan könnyű (Ostovar, 2019, 185-187. o.).

Végüil, de nem utolsósorban, a regionális túlterjeszkedés komoly belpolitikai következményekkel járhat; a proxyhadviselés nem kerül ugyan sokba, a gazdasági nehézségek (lásd: Fórián-Szabó és Kovács, 2021) azonban próbára tehetik a rendszer legitimációját - ahogyan azt a 2019-es tüntetések is jól mutatták: „Ne Szíriára, hanem ránk figyeljetek!" (Fassihi és Gladstone, 2019).

A nem állami kapcsolatrendszer sok szempontból kényszer szülte megoldás, ám egyben tudatos tervezés és hosszú építkezés eredmé nye is. A teheráni rezsim fáradságos munkával hozta létre az „ellen állás tengelyét", a militáns partnerek Libanontól Szírián át Jemenig terjedô hálózatát. Ez a transznacionális csoportosulás (amely elsősorban a hidegháborús értelemben vett forradalmiságon, nem pedig a síita vallási kapesolaton alapszik) számos úton-módon szolgálja az iráni vezetés stratégiai céljait. Többek közt az Iráni Iszlám Köztársaság megjelenhet általuk a közel-keleti konfliktusokban, érvényre jut tathatja az érdekeit, vagy legalábbis blokkolhatja az ellenségei törekvéseit, és - nem utolsósorban - meggyơző elrettentő erôt mutathat a rezsimet fenyegető külső (nagy)hatalmak felé. Ugyanakkor az eltúlzott militáns kapcsolatoknak, illetve a felforgató tevékenységeknek megvannak az árnyoldalai is, és azok (tovább) rombolják Teherán renoméját, a szomszédságban fenntartják az instabil helyzeteket, ezáltal pedig tulajdonképpen szűkítik az iráni vezetés regionális mozgásterét (Vatanka, 2018, 1-15. o.). 


\section{Nem állami szereplők a gyakorlatban - az „ellenállás tengelyének" bemutatása}

Irán kiterjedt és meggyőző nem állami kapcsolatrendszert hozott létre maga körül, mindazonáltal ez a hálózat képlékeny és komplex: az „ellenállás tengelye” nem tekinthető konszolidálódott szövetségi rendszernek, mivel nincsenek írott egyezményeik, még kevésbé kőbe vésett szabályaik, amelyek szorosan összefognák a szereplőket. Az egyuittmúködés az emocionális és vallásos narratívák mentén szerveződik, a konstruált és vizionált ellenségképek ellen irányul, valójában azonban a viszonyrendszert az érdekek „szerencsés” egybeesése és a teheráni vezetés ügyes taktikázása múködteti. A szövetségben az Iráni Iszlám Köztársaság áll a középpontban, de Teherán nem irányítja vagy utasítja, sokkal inkább menedzseli és szervezi a sokszínű nem állami szereplőgárdát - tulajdonképpen rendkívüil decentralizált és funkcionális együittműködési formulát alakítva ki a partnereivel (Katz, 2018, 4-6. o.).

Irán nem állami kapesolatai dinamikus síkon mozognak, a helyi fegyveres csoportokkal való kooperáció mélysége és milyensége számos tényezőtől függ. Elôször is attól, hogy van-e a felek között komolyabb történelmi kapcsolódás, messzire nyúló társadalmi-politikai interakció és kiterjedt kulturális-vallási reláció. Másodszor, hogy létezik-e szorosabb ideológiai egyezés és kötődés, azaz az adott nem állami szereplő milyen szinten tud azonosulni az iszlám köztársaság koncepciójával, még inkább Ali Khamenei legfőbb vezető elvi és politikai iránymutatásával. Harmadszor, hogy van-e stratégiai együttműködés, a ,játékosok” tudnak-e vállvetve küzdeni a regionális rend átalakítása és a biztonsági kihívások ellensúlyozása érdekében, vagy inkább csak a helyi konfliktusokra koncentrálnak. Negyedszer, a hatékonyság kér dése is lényeges: az adott kötelékek milyen költségekkel járnak, és főleg milyen kölcsönös politikai előnyszerzéssel kecsegtethetnek - a stabil hátország megteremtésével vagy csupán a zavarkeltés lehetőségével (International Institute of Strategic Studies, 2020, 1-7. o.). Számításba lehet venni még más faktorokat is, például a földrajzi távolságot, az 


\section{Külïgyi Szemle}

iráni stratégiai gondolkodás prioritási köreit, a nem állami partnerek intézményi szervezettségét, személyi kapcsolataik kiforrottságát, illetve az eszközeik milyenségét és a forrásaik mértékét. Ez utóbbi különösen fontos, hiszen meghatározhatja, hogy milyen szoros teheráni irányítás alatt múködik az adott viszonyrendszer (Tabatabai, Martini és Wasser, 2019, 1-9. o.). E szempontok alapján a széles és színes iráni nem állami kapcsolatrendszerben szoros ideológiai szövetségest, stratégiai partnert, valamint „valódi” proxyszerveződést egyaránt találunk.

Az Iráni Iszlám Köztársaság által támogatott nem állami szereplők közül minden kétséget kizáróan a Hezbollahnak van a legnagyobb jelentősége: a teheráni vezetésnek a libanoni szervezet a legfontosabb és egyben a legszorosabb ideológiai szövetségese a közel-keleti játszmákban (Seliktar és Rezaei, 2020, 21-52. o.). Az Irán és Libanon közti társadalmi és vallási kötelékek évszázadokra nyúlnak vissza: a síita iszlám a dél-libanoni régióból „érkezett” Perzsiába a Szafavidadinasztia uralkodása idején, a 16. század elején (a vallás elterjedésében meghatározó szerepük volt a libanoni misszionáriusoknak), az 1970es években pedig az iráni Qom városából mentek síita vallástudósok a vallási tanokat propagálni Libanonba (a helyi síita közösségek mobilizálásában is kulcsjelentőségüik volt az iráni teológusoknak) (Chehabi, 2007, 1-49. o.). A többi nem állami aktorral ellentétben a Hezbollahot tulajdonképpen a teheráni vezetés hozta létre: az „Isten pártjának” megszervezéséhez a Forradalmi Gárda 1000-1500 katonája nyújtott segítséget, az iráni rezsim pedig lényegében azóta is komoly szerepet vállal a síita szervezet kiképzésében, felfegyverzésében, taktikai felkészítésében, valamint a pénzügyi segélyezésében (egyes becslések szerint évi 700-1000 millió dollárral támogatja a csoportot) (Williams, 2018). A Hezbollah az egykori gerillamozgalomból napjainkra Libanon egyik legerősebb és legbefolyásosabb szerveződése lett: a síita csoportnak meghatározó szerepe van a politikai, gazdasági és társa dalmi alrendszerekben - mondhatni, igazi állam az államban (Byman, 2008). 
Az Iráni Iszlám Köztársaság nemcsak paramilitáris kereteket alkotott, hanem egyben politikai és ideológiai sarokpontokat is "adott" a Hezbollah számára: a szervezet központi célkitűzése az iráni berendezkedéshez hasonló iszlám kormányzat kiépítése lett, a vezetỏi pedig nem egyszerủen politikai iránytúként, inkább egyfajta központi autoritásként is tekintenek a teheráni legfóbb vallási vezetésre (Feltman, 2019). Politikai pártként olyan hatalmi erỏvé változott (a szunnita és a keresztény eróközpontok mellett), amely képes ellenőrizni a gyenge állami berendezkedést, leküzdeni a rivális pártokat, alakítani a napirendi pontokat, valamint befolyásolni (vagy éppen blokkolni) az ország haladásának az irányát (Khatib, 2021, 5-12. o.). A Hezbollahnak jelenleg 12 képviselője van a 128 fős parlamentben, a Hủség az Ellenállási Blokkhoz (a szervezet politikai szárnya) a törvényhozás egyik legnagyobb frakcióját alkotja, a Március 8. koalíció tagjaként pedig kor mányzati tisztségekkel is rendelkezik (Hubbard és Saad, 2018).

A síita szervezet emellett számtalan úton-módon van jelen az or szág társadalmi „szövetében” (a népesség nagyjából 30 százalékát ki tevő síiták körében). Így például a kiterjedt médiabirodalmán (köztük az al-Manár tévé- és az al-Núr rádiócsatornán) keresztül interpretálja és kommunikálja a fontos eseményeket, széles iskolarendszer fenntartásával alakítja az ideológiai nevelést, formálja a politikai gondolkodást, illetve különféle vallási alapítványok révén biztosítja a szociális ellátást és támogatást a rászoruló lakosságnak (Norton, 2007, 475491. o.). Ezek a síta jótékonysági szerveződések - az iráni modellt követve - rendkívül kiterjedt vállalkozásokat múködtetnek, amelyek az elmaradott vidéki (vagy háború sújtotta) területek infrastrukturális fejlesztésében (és rekonstrukciójában) kulcsszerepet játszanak, s ez zel építik a szervezet társadalmi népszerűségét és erôsítik a politikai legitimitását (lásd pl. a Dzsihád al-Biná vallási alapítványnak a síita közösségekben folytatott segélyező és vidékfejlesztő tevékenységét) (Lob, 2019, 411-442. o.).

A Hezbollahnak a libanoni meghatározó erővé válása egyfajta stra tégiai „hátországot” biztosít az Iráni Iszlám Köztársaságnak a levantei régióban. A síita szerveződés a politikai, gazdasági és társadalmi 


\section{Külïgyi Szemle}

minták másolásával erősíti a teheráni rezsim támogatottságát, előse gíti annak hatalmi pozícionálását, és lehetőséget teremt a külkapcso latai alakítására is (pl. a nemzetközi szankciók megkerülésére). Fontos azonban megjegyezni, hogy a rendkívül bonyolult libanoni politikai erôtérben a szunnita vallási szerveződések a saját tevékenységüikkel hasonló társadalmi pozíciót biztosítanak az őket támogató arab álla moknak is.

A Hezbollah megszervezésével a cél az volt, hogy a történelmi, vallási, érzelmi kapcsolatokra építve egyfajta stratégiai hídfóállást biztosítson a teheráni tervezés számára az Izraellel szembeni küzde lemben, továbbá a politikai erőszak küiönböző formái (pl. emberrablások és terrorcselekmények) révén minél nagyobb veszteséget okozzon a zsidó államnak és nyugati szövetségeseinek (Norton, 2018, 32-34. o.). A 2006-os izraeli-libanoni háború jól mutatta, hogy ez a fegyve res szerveződés milyen komoly aszimmetrikus katonai képességekkel rendelkezik, illetve képes önállóan és határozottan fellépni a saját érdekei védelmében. Az „arab tavasz” óta eltelt tíz évben pedig igazi regionális transznacionális milíciává terebélyesedett, a Közel-Kelet legerősebb és legütőképesebb nem állami szereplőjévé lett. Közvetlenül bekapcsolódik a határain túli konfliktusokba, küllöldi expedíciós hadmúveleteket hajt végre - többek között az Aszad-rezsim hatalomban tartása érdekében több ezer katonával van aktívan jelen a szomszédos Szíriában (részt vett az ellenzéki terüiletek visszafoglalásában is) (Blanford, 2017, 7-10. o.). Habár egyeztet Teheránnal, az akcióit mégis önállóan hajtja végre, Kászem Szolejmáni halála óta pedig csak még inkább szélesedett a mozgástere.

A szervezet igazi „paramilitáris mentorként” egyre nagyobb sze repet játszik a szövetséges fegyveres erők kiképzésében, így a kez detektől fogva oroszlánrészt vállal az iraki népi milíciáknak a harcra való felkészítésében (újabban a jemeni felkelőket is tanácsokkal látja el). Ahogyan azt az egyik parancsnoka megfogalmazta: „Már nem csak egy párt vagyunk, nemzetközivé váltunk... Mi vagyunk az az is kola, ahol minden szabadságvágyó ember tanulni akar" (Lewitt, 2021, 22. o.) Egyfajta „logisztikai központként” igen komoly financiális és 
infrastrukturális segítséget nyújt az „ellenállás tengelyének”, tulajdonképpen a teheráni vezetést tehermentesítve segít menedzselni a nem állami relációkat (például fegyverekkel, pénzzel, kapcsolatokkal), valamint biztos bejrúti menedékekkel támogatja a húszi lázadókat (Tabatabai és Clarke, 2019). Széles nemzetközi kapcsolatrendszerrel rendelkezik, számos csempészvállalkozást múködtet, kiterjedt nem zetközi propagandatevékenységet folytat (Ázsiától Afrikán át Amerikáig képes akciókat végrehajtani). Teherán nézőpontjából a Hezbollah nem csupán politikai siker, hanem igazi stratégiai előny, megbízható és ügyes partner, amelyet abban az esetben, ha modern haditechnikával (új harci drónokkal) szereli fel, taktikai tervekkel támogatja meg, és beemeli a közel-keleti játékba, sikeresen fokozhatja az erőkivetítési képességét (International Institute of Strategic Studies, 2020, 82-84. o.).

Az Iráni Iszlám Köztársaság és a Hezbollah közti viszony közel négy évtized után is nagyon szorosnak-stabilnak tekinthető, ami a közös célok, érdekek, értékek, félelmek, normák, sikerek, tapasztalatok mellett leginkább négy tényező következménye:

- a Hezbollah széles körủ autonómiát élvez, önállóan tevékenykedhet, mert Teherán tudatosan igyekszik távolságot tartani, hagyni, hogy a szervezet maga intézze az ügyeit (pl. a harcosok toborzását vagy az akciók megszervezését) és szabadon alakítsa ki az álláspontját a belpolitikai kérdésekben (pl. a politikai szerepvállalás ügyében vagy az egyes szakpolitikai döntések során); a Hezbollah teljes ellenőrzést gyakorolhat a költségvetése fe lett, hiszen az iráni pénzügyi támogatások mellett számos saját bevételi forrással is rendelkezik (s azok hatékonyan és igen felelősségteljes felhasználására törekszik);

- az őszinte elkötelezettség és a szilárd bizalom (és persze a szoros vallási és ideológiai kötelékek) eredményeként a felek mindenkor tartózkodnak az önérdekkövető („opportunista”) magatartástól: egyfajta rugalmasság jellemzi a szereplỏket, a felmerüilő vitás ïgyekben pedig hosszú és kimerítő egyezteté seket folytatnak (az együittmúködésük rutinszerúvé és intéz ményesítetté vált); 


\section{Külïgyi Szemle}

- a geopolitikai érdekek, a biztonsági fenyegetések, a társadalmi törésvonalak és az államközi versengések egyaránt az Iráni Iszlám Köztársaság és a Hezbollah közti speciális viszonyrendszert erősítik (stabilizálják) - az elmúlt évtizedben a regionális instabilitás fokozódásával pedig még inkább felértékelődött a felek közötti együttműködés (Khan és Zhaoying, 2020, 101-123. o.).

Ugyanakkor, habár a Hezbollah sikeres transznacionális eróvé vált az Iráni Iszlám Köztársaság oldalán, ez a kapcsolat nem egyoldalú: Teherán inkább használja, mintsem irányítja a libanoni félállami szerveződést. A síita szervezet nagyon sokat köszönhet az iráni forradalmi vezetésnek, de mára önálló szereplővé lépett elő a közel-keleti térségben: saját identitással, anyagi forrással, katonai eszközparkkal, vezetési hierarchiával és - nem utolsósorban - saját érdekrendszerrel rendelkezik (és azt láthatóan igyekszik is önállóan megvalósítani).

Irakban és Szíriában a népi milíciák lényegében proxypartnerként segítik Teherán elrettentő és erőkivetítő befolyásszerzését. Habár ma egyre nagyobb, „államibb” szerepük van, a biztonsági és politikai céljaik, materiális és spirituális forrásaik, illetve hadmúveleti és hírszerzési támogatásaik tekintetében még mindig erősen függenek az iráni vezetéstől (Jones, 2019, 1-16. o.). E fegyveres csapatokat az Iráni Iszlám Köztársaság a baráti államok és reguláris hadseregek meggyengülése miatt kezdte el szervezni és támogatni, hogy így segítse a kormányzatokat az ellenzéki, illetve a radikális iszlamista erőkkel szembeni küzdelemben, az elveszített területeik visszaszerzésében. Ezek a milíciák alkalmasak a kurd önrendelkezési kezdeményezések letörésére, Washington térségbeli pozíciói és érdekeltségei meggyengítésére (célzott erőszak alkalmazására), illetve az iráni stratégiai mélység kiépítése érdekében egy „Libanonig érő szárazföldi korridor” formálására (Behravesh, 2020, 9-11. o.).

Teherán hosszabb távra kíván berendezkedni, ezért megpróbál minél több helyi szerveződéssel kapcsolatot kialakítani, hogy bárki is kerül hatalomra (vagy netán megtörténne a területi szétesés), biztosan legyen olyan megbízható partnere, amely befolyást biztosíthat 
az érdekei érvényesítéséhez (Lane, 2021). Irán komoly erőkkel van je len az adott konfliktusokban (különösen Szíriában), de kellő távolságot igyekszik tartani, és inkább a háttérből kíván irányítani, és alapvetően a katonai kiképzésre, a taktikai tervezésre és a személyi kötelékek kialakítására akar összpontosítani. A megszerzett pozíciói megörzése érdekében a nem állami partnereit a konszolidáció során is igyekszik felhasználni: egyfelől megpróbálja a milíciákat politikai erővé alakítani (pártok, választási koalíciók létrehozásával intézményesíteni a tár sadalmi támogatottságát), másfelól megkísérli a fegyveres csapatok nak a biztonsági intézményrendszerbe történő integrálódását kihasz nálni (a kulesfontosságú belbiztonsági-titkosszolgálati szervezetekbe ültetett megbízható emberei révén biztosítani a politikai befolyását) (Felbab-Brown és Haddad, 2020, 30-65. o.).

A sok milícia közül érdemes megemlíteni a Katáib Hezbollah nevű szerveződést, amely az Iráni Iszlám Köztársaság leglényegesebb patronáltja Irakban. A csoportot nagyon szoros ideológiai szálak füzik Teheránhoz: a legjelentősebb iraki síita vallástudóssal, Ali Szisztáni nagyajatollahhal szemben a teheráni vallási vezetéshez lojális, és az iráni politikai modellt másolja, és ugyanolyan vehemensen támadja Washingtont, mint Irán. Ráadásul nemcsak komoly (tízezer fős) katonai erővel bír, hanem fontos politikaformáló képességgel is rendelkezik (a 2018-as választáson a Fatah-koalíció tagjaként parlamenti képviseletre tett szert) (Majidyar, 2018).

Az iráni regionális biztonsági-hatalmi törekvésekben a jemeni húszi felkelőkkel (Anszár Allah) való kapcsolat az érdekek egybeesésének eredményeként, egyfajta ad hoc szövetségként jött létre, mára azonban komplexebb és kiterjedtebb stratégiai partnerséggé fejlődött (International Institute of Strategic Studies, 2020, 159178. o.). Irán a húszi lázadók egyre határozottabb támogatásával Szaúd-Arábia közvetlen szomszédságában igyekszik zavart kelte ni, kellően lekötni Rijád erejét és figyelmét, költséges háborúba kényszeríteni és más konfliktusokban gyengíteni annak befolyáso ló képességét. Továbbá megpróbálja megvetni a lábát a Báb elMandeb-szorosban, hogy (retorikailag) fenyegetés alatt tarthassa a 


\section{Külïgyi Szemle}

kulcsfontosságú tengeri kereskedelmi-szállítási útvonalakat, valamint bizonyithassa a regionális nagyhatalomkénti kiterjedtségét (Juneau, 2021, 647-663. o.). Emellett a jemeni harcmező egyfajta kísérleti laboratóriumként is szolgál, ahol Irán a gyakorlatban teszteli az új és ütőképes haditechnikai eszközeit (lásd pl. a szaúdi célpontok ellen végrehajtott rakétatámadásokat) (International Institute of Strategic Studies, 2020, 159-178. o.). A húszi lázadók számára rendkíviul fontos a teheráni támogatás, mivel nines más megbízható partnerük, amely pénzzel és fegyverrel segítené a szaúdi hadsereggel szemben vívott küzdelmüket. Emellett bizonyos ideológiai sarokpontokban (az USAés Izrael-ellenességben) és regionális célkitűzésekben (pl. az amerikai és a szaúdi pozíciók gyengítésében) is azonos véleményen vannak az iráni vezetéssel (Johnston, 2020, 51-72. o.).

Habár a felek között jól azonosíthatóak a konstruktív történelmi kötelékek és stratégiai érdekegyezések, azonban látni kell a vallási és ideológiai különbözőségeket is. Teherán népszerű ugyan a lázadók körében, de a húszik nem a tizenkettes dzsafarita irányzatot követik, mint Irán, hanem a síita iszlám egy másik, lényegesen kevesebb követővel rendelkező ágához tartoznak: zeiditák. Ráadásul míg az an tiimperialista (antikolonialista) retorika vonzó a számukra, addig az iszlám köztársasági modell átvétele már egyáltalán nem célja a politikai-hatalmi törekvéseiknek (így nem tekintik a politikai vezetőjüknek Ali Khamenei ajatollahot, és nem követik az ideológiai iránymutatá sait) (Kendall, 2017, 1-11. o.). Továbbá Jemen földrajzilag is távol van, mivel az iráni stratégiai gondolkodásban a szúkebb Perzsa-öböl és a levantei régió kap egyértelmú prioritást. Noha egyre mélyebb kooperáció figyelhetô meg a húszi lázadók, a Hezbollah és Teherán között, a mozgalom mégsem kapcsolódott be látványosabban a szélesebb regionális hadmúveletekbe (Seliktar és Rezaei, 2020, 220-229. o.). Öszszességében véve azonban az iráni vezetésnek előnyös a jemeni felkelőkkel kialakított viszonyrendszer, hiszen általuk minimális anyagi befektetéssel és csekély katonai jelenléttel is nagyon komoly stratégiai előnyökre tehet szert az Arab-félszigeten. 
Az Iráni Iszlám Köztársaság a felsoroltakon kívül még számos nem állami kapcsolattal rendelkezik. Az egyik leglényegesebb a palesztin szerveződésekkel (pl. a Hamásszal és az Iszlám Dzsiháddal) ápolt viszony, amely egyfelől Libanon mellett egy második frontot biztosít az Izrael elleni harcban, másfelől lehetőséget kínál, hogy Irán a közel-keleti törésvonalakon túllépve, szélesebb körû népszerūségre próbáljon szert tenni az arab és szunnita világban, továbbá egyfajta hadszínte ret jelent, ahol a szélesebb regionális hatalmi versengésben a teheráni vezetés sikeresen pozícionálhatja magát az ellenlábasaival szemben (Brandenburg, 2010). Az „elnyomott palesztinok” ügyének felkarolása tulajdonképpen a kezdetektől fogva központi témája-eszköze a forradalmi külpolitikának, a vallási vezetés pénzzel és fegyverrel támogat ja az említett mozgalmakat - elég megemlíteni a precízen kiépített fegyvercsempész-útvonalakat, illetve a helyi rakéta-összeszerelö üze meket (Nissenbaum, Rasmussen és Faucon, 2021). Bár a narratívának a lényeges elemét adja, valójában csak „távoli” partnerségről van szó, hiszen Irán fegyveres erőkkel nincs jelen a területen, ráadásul ezek a csoportok az Izrael-ellenességen túl a fontosabb regionális biztonsági ügyekben nem múködnek szorosan együtt Teheránnal (pl. a szíriai polgárháborút attól eltérően értelmezik, és az Aszad-rezsim ellenzékével szimpatizálnak) (Vohra, 2021).

Teherán nem állami kapcsolatai közüil érdemes még megemlíteni azokat a síita ellenzéki mozgalmakat is, amelyek az öbölmonarchiák ban (pl. Bahreinben, Kuvaitban és Szaúd-Arábiában) múködnek, és az adott kormányzatokat hivatottak „bosszantani”. Ezeknek komolyabb hatásuk nincsen, mivel a helyi körülmények, az államok relatív ereje és a teheráni vezetés rizikókerülő önmérséklete gátolja az aktív ténykedésüket (International Institute of Strategic Studies, 2020, 179-194. o.).

Összességében Teherán egyfajta költség-haszon számítás alapján. a kapcsolatok ideológiai, logisztikai, pénzügyi, politikai, stratégiai, il letve társadalmi dimenzióinak a számbavételével alakítja az aktuális nem állami viszonyrendszereit. Ennek megfelelően négy funkcionális együttműködési modellt, illetve annak megfelelő partnert lehet megfigyelni: 


\section{Külïgyi Szemle}

- a „célzók”, akik támadják-gyengítik az ellenfelek pozícióit (pl. az iraki síita népi milíciák);

- az „elrettentők”, akik megfélemlítik-bosszantják a rezsim regionális ellenségeit (pl. a húszi felkelők);

- a „stabilizálók”, akik fegyveres akcióikkal támogatják és segítik a szövetségek kialakítását (pl. a síita zsoldosseregek), valamint

- a „befolyásolók”, akik a formális állami politikai-biztonsági struktúrákba illeszkedve képviselik, illetve érvényesítik a tehe ráni érdeket (pl. a libanoni Hezbollah) (Tabatabai et al., 2019, 9-19. о.).

Egy-egy nem állami szerveződés egyszerre több feladatot láthat el, a kitűzött teheráni célok és a regionális viszonyok alakulásának eredményeként pedig időről időre változhat és módosulhat a kooperációk természete és mélysége. Ezek a funkcionális és flexibilis nem állami kapcsolatok rendkívül változatos stratégiai tervezést és cselekvést tesznek lehetővé, s alkalmasak arra, hogy Teherán a céljait és a lehetőségeit szem előtt tartva alakíthassa a közel-keleti folyamatokat.

\section{Befejezó gondolatok}

A Közel-Kelet karakterisztikájából adódóan, azaz a problémás poli tikai berendezkedések, a vallási és társadalmi ellentétek, a csillapít hatatlan hatalmi versengések, valamint a megoldhatatlan konfliktu sok következményeként tovább folytatódik a térségben megfigyelhető „hibridizációs” trend, a nem állami szereplők térnyerése, a védelmi, szociális vagy éppen kulturális feladatok kiszerveződése. A vákuumhelyzetek feloldása, a jelenleg zajló szíriai és jemeni polgárháborúk békés lezárása, a politikai rendezés, a gazdasági újjáépítés, a társadalmi megbékélés, valamint a civil-katonai professzionalizálódás megvalósítása mind-mind nehéz feladatnak tűnik. A nem állami szereplők a decentralizált jellegük és a paramilitáris múködésük következtében sok esetben inkább felerősítik, mint megoldják a meglévő feszültségeket. A regionális hidegháborút vívó Irán és Szaúd-Arábia szektariánus 
narratívája szintén megnehezíti az érdemi és hosszú távú rendezést, ráadásul Afganisztán destabilizálódásával új front is nyillhat a viaskodásukban.

A jelenlegi közel-keleti helyzet alapján megállapítható, hogy az iráni stratégia sikeresnek bizonyul: a „militáns partnerei” által kínált nem hagyományos hadviselés, a konfliktusokban edződött milíciák közti kötelék, a harctéri és hadmúveleti együttmúködés komoly erőt biztosít Teheránnak, a fegyveres nem állami szereplők lokális meg erősödése pedig politikai, társadalmi és gazdasági befolyásszerzést biztosíthat az iráni rezsimnek a konszolidációs és rekonstrukciós idő szakban. Irán most kétségkíviil magabiztosnak látszik, de a teheráni vezetésnek komoly nehézségekkel is szembe kell néznie. Egyrészt a taktika koncepcionális hibáival, többek között a szomszédos országok kal való kapcsolatok megromlásával, a konfliktusok eszkalálódásával vagy éppen a sokszínú szövetségi viszonyok gyengülésével. Másrészt szélesebb körű strukturális problémákkal is szembekerül, így például a szúkös pénzügyi keretekkel és az igencsak erodálódott társadalmi támogatással. Végül, de nem utolsósorban, az új biztonsági kihívások jelentkezése és a regionális környezet formálódása, valamint a külsô nagyhatalmi szereplők érdekeinek és törekvéseinek a mindenkori alakulása is jelentősen befolyásolja Teherán lehetőségeit.

\section{Irodalomjegyzék}

Abadi, Jacob (2019). Saudi Arabia's Rapprochement with Israel: The National Security Imperatives. Middle Eastern Studies, 55(3), 433-449.

Adebahr, Cornelius, Berti, Benedetta, Eljarh, Mohamed és Kausch, Kristina (2016). Power Beyond the State: Non-State Actors in the Broader Southern Mediterranean. Konrad Adenauer Sliflung. A letöltés ideje: 2021. szeptember 10. https:/www.kas.de/en/web/poldimed/ veranstaltungsberichte/detail/-/content/power-bevond-the-state-nonstate-actors-in-the-broader-southern-mediterraneanl. 


\section{Külïgyi Szemle}

Ahmadian, Hassan és Mohseni, Payam (2019). Iran's Syria Strategy: The Evolution of Deterrence. International Affairs, 95(2), 344-348.

Ali, Hassanein (2020). Post-Arab Spring: The Arab World Between the Dilemma of the Nation-State and the Rise of Violent Non-State Actors. Asian Journal of Middle Eastern and Islamic Studies, 14(1), 68-83.

Arany Anett, N. Rózsa Erzsébet és Szalai Máté (2016). Az Iszlám Állam Kalifálusa: Az álalakuló Közel-Kelet. Budapest: Osiris Kiadó.

Ataie, Mohammad (2021). Continuity Despite Revolution: Iran's Support for Non-State Actors. Brandeis University Crown Center for Middle East Studies. A letöltés ideje: 2021.július 10. https://www.brandeis.edu/crown/ publications/middle-east-briefs/pdfs/101-200/mebl4l.pdf.

Aydinli, Ersel (2015). Assessing Violent Non-State Actorness in Global Politics: A Framework for Analysis. Cambridge Review of International Affairs, 28(3), 424-444.

Bajoghli, Narges (2019). The Hidden Sources of Iranian Strength. Foreign Policy. A letöltés ideje: 2021. szeptember 15. https://foreignpolicv. com $/ 2019 / 05 / 15 /$ the-hidden-sources-of-iranian-strength.

Behravesh, Maysam (2020). Iran's Unconventional Alliance Network in the Middle East and Beyond. Middle East Institule. A letöltés ideje: 2021. augusztus 15. https://www.mei.edu/ publications/irans-unconventionalalliance-network-middle-east-and-bevond.

Blanford, Nicholas (2017). Hezbollah's Evolution: From Lebanese Militia to Regional Player. Middle East Instilule. A letöltés ideje: 2021. augusztus 15. https://www.mei.edu/publications/ hezbollahs-evolution-lebanesemilitia-regional-plaver.

Borger, Julian és Smith, David (2017). Trump Administration Imposes New Sanctions on Iran. The Guardian. A letöltés ideje: 2021. augusztus 15. https:/www.theguardian.com/us-news/ 2017/feb/03/trumpadministration-iran-sanctions.

Brandenburg, Rachel (2010). Iran and the Palestinians. Iran Primer. A letöltés ideje: 2021. augusztus 15. https://iranprimer.usip.org/resource/ iran-and-palestinians.

Byman, Daniel L. (2008). Hezbollah: Most Powerful Political Movement in Lebanon. Council on Foreign Relations. A letöltés ideje: 2021. augusztus 15. https://web.archive.org/web/20130617010638/http:/www.cfr.org/ lebanon/hezbollah-most-powerful-political-movement-lebanon/ pl6378?breadcrumb $=\% 2 \mathrm{~F}$. 
Chehabi, Houchang E. (2007). Distant Relations: Iran and Lebanon in the Last 500 Years. New York, NY: I.B. Tauris.

Clausen, Maria-Louise (2020). Iran's Successful Transnational Network: Iranian Foreign Policy Utilizes Partner. Danish Institute for International Studies. A letöltés ideje: 2021. augusztus 10. https:/pure.diis.dk/ws/ files/3779688/DIIS_PB_Iran_s_successful_transnational_network_3. pdf.

Csicsmann, László (2021). A szankciók mint a nyomásgyakorlás eszközei a nemzetközi kapcsolatokban: a Közel-Kelet és Irán esete. Külïgyi Szemle, $20(3), 80-112$.

Durac, Vincent (2015). The Role of Non-State Actors in Arab Countries After the Arab Spring. IE Medilerranean Yearbook. A letöltés ideje: 2021. augusztus 25. https://www.iemed.org/wp-content/uploads/2021/01/ The-Role-of-Non-State-Actors-in-Arab-Countries-after-the-ArabUprisings.pdf.

Esfandiari, Golnaz (2020). Iranian Media Confirm Quds Force Involvement in Foreign Conflicts. Radio Free Europe. A letöltés ideje: 2020. július 30. https:/www.rferl.org/a/ iranian-media-confirm-quds-forceinvolvement-in-foreign-conflicts/30408664.html.

Fassihi, Farnaz és Gladstone, Rick (2019). With Brutal Crackdown, Iran Is Convulsed by Worst Unrest in 40 Years, The New York Times. A letöltés ideje: 2021. augusztus 15. https://www.nvtimes.com/2019/12/01/world/ middleeast/iran-protests-deaths.html.

Felbab-Brown, Vanda és Haddad, Fanar (2020). Hybrid Conflict, Hybrid Peace: How Militias and Paramilitary Groups Shape Post-Conflict Transilions. New York, NY: United Nations University.

Feltman, Jeffrey (2019). Hezbollah: Revolutionary Iran's Most Successful Export. Brookings. A letöltés ideje: 2021. július 5. https://www.brookings. edu/opinions/hezbollah-revolutionary-irans-most-successful-export.

Fórián-Szabó Viktor és Kovács Tamás (2021). Terhelő örökség. Az iráni gazdaság lehetőségei és kihívásai a 2021-es elnökválasztás után. Külïgyi Szemle, 20(3), 38-79.

Gardner, Frank (2019). Iran's Network of Influence in Mid-East 'Growing'. BBC. A letöltés ideje: 2021. július 30. https://www.bbc.com/news/worldmiddle-east 50324912 .

Gause, Gregory (2014). Beyond Sectarianism: The New Middle East Cold War. Brookings Doha Center. A letöltés ideje: 2021. augusztus 10. https:// www.brookings.edu/wp-content/ uploads/2016/06/English-PDF-1.pdf. 


\section{Külïgyi Szemle}

Hubbard, Ben és Saad, Hwaida (2018). Lebanon Elections Boost Hezbollah's Clout. The New York Times. A letöltés ideje: 2021. augusztus 5. https:// www.nvtimes.com $/ 2018 / 05 / 07 /$ world/ middleeast/lebanon-electionhezbollah.html.

International Institute of Strategic Studies (2020). Iran's Networks of Influence in the Middle East. New York, NY: Routledge.

Johnston, Trevor (2020). Could the Houthis Be the Next Hizballah? Santa Monica, CA: RAND Corporation. A letöltés ideje: 2021. augusztus 10. https://www.rand.org/content/dam/rand/pubs/research_reports/ RR2500/RR2551/RAND_RR2551.pdf.

Jones, Seth G. (2019). War by Proxy Iran's Growing Footprint in the Middle East. Center for Strategic and International Studies. A letöltés ideje: 2019. július 25. https://csis-website-prod.s3.amazonaws.com/s3fs-public/ publication/190312_IranProxvWar_FINAL.pdf.

Juneau, Thomas (2021). How War in Yemen Transformed the Iran-Houthi Partnership. Studies in Conflict \& Terrorism, 92(3), 647-663.

Kamel, Lorenzo (2017). The Frailty of Authority: Borders, Non-State Actors and Power Vacuums in a Changing Middle East. Istiluto A/fari Internazionali. A letöltés ideje: 2020. július 30. https://www.iai.it/sites/ default/files/newmed authority.pdf.

Katz,Brian (2018). Iran's EvolvingRegional Strategy \& Non-StatePartnerships in the Middle East. Center for Stralegic and International Studies. A letöltés ideje: 2021. július 30. https://www.csis.org/analysis/axisrising-irans-evolving-regional-strategy-and-non-state-partnershipsmiddle-east.

Kausch, Kristina (2017). State and Non-State Alliances in the Middle East. The International Spectator, 52(3), 36-47.

Kendall, Elisabeth (2017). Iran's Fingerprints in Yemen: Real or Imagined? Allantic Council. A letöltés ideje: 2021. augusztus 15. https:/www. atlanticcouncil.org/wp-content/uploads/2017/10/Irans_Fingerprints in Yemen web_1019.pdf.

Khan, AkbarésZhaoying, Han (2020). Iran-Hezbollah Alliance Reconsidered: What Contributes to the Survival of State-Proxy Alliance? Journal of Asian Security and International Affairs, 7(1), 101-123.

Khatib, Lina (2021). How Hezbollah Holds Sway over the Lebanese State. Chatham House. A letöltés ideje: 2021. augusztus 25. https://www. chathamhouse.org/sites/default/files/2021-07/2021-06-30-howhezbollah-holds-swav-over-the-lebanese-state-khatib.pdf. 
Kirkpatrick, David D. (2019). Who Was Behind the Saudi Oil Attack? What the Evidence Shows. The New York Times. A letöltés ideje: 2021. július 30. https:/www.nvtimes.com/ interactive/2019/09/16/world/middleeast/ trump-saudi-arabia-oil-attack.html.

Lane, Ashley (2021). Iran's Islamist Proxies in the Middle East. Wilson Center. A letöltés ideje: 2021. augusztus 15. https:/www.wilsoncenter. org/article/irans-islamist-proxies.

Lewitt, Matthew (2021). Hezbollah's Regional Activities in Support of Iran's Proxy Networks. Middle East Instilute. A letöltés ideje: 2021. augusztus 15. https://www.mei.edu/publications/ hezbollahs-regional-activitiessupport-irans-proxy-networks.

Lob, Eric (2019). Iran and Hizbullah's Development Organization in Lebanon: The Case of Jihàd al-Bina. Die Welt des Islams, 59(3-4), 411-442.

Majidyar, Ahmad (2017). Iran Recruits and Trains Large Numbers of Afghan and Pakistani Shiites. Middle East Institule. A letöltés ideje: 2021. augusztus 10. https://www.mei.edu/ publications/iran-recruits-andtrains-large-numbers-afghan-and-pakistani-shiites.

Majidyar, Ahmad (2018). Iran-Backed Fateh Alliance Seeks to Win or Play Kingmaker in Upcoming Iraqi Elections. Middle East Instilute. A letöltés ideje: 2021. augusztus 15. https:/www.mei.edu/publications/ iran-backed-fateh-alliance-seeks-win-or-plav-kingmaker-upcomingiraqi-elections.

Middle East Institute (2020). After Qassem Soleimani: The Islamic Republic's Strategy for the Arab World. A letöltés ideje: 2021. augusztus 10. hhtps://www.mei.edu/events/after-qassem-soleimani-islamicrepublics-strategy-arab-world.

N. Rózsa Erzsébet (2018). Models of State-Formation in the Middle East. Asian Journal of Middle Eastern and Islamic Studies, 12(1), 16-34.

Nissenbaum, Dion, Rasmussen, Sune E. és Faucon, Benoit (2021). With Iranian Help, Hamas Builds 'Made in Gaza' Rockets and Drones to Target Israel. The Wall Streel Journal. A letöltés ideje: 2021. augusztus 25. https:/www.wsj.com/articles/with-iranian-help-hamas-buildsmade-in-gaza-rockets-and-drones-to-target-israel-11621535346.

Norton, Augustus R. (2007). The Role of Hezbollah in Lebanese Domestic Politics. The International Spectator, 42(4), 475-491.

Norton, Augustus R. (2018). Hezbollah: A Shorl History. Princeton: Princeton University Press. 


\section{Külïgyi Szemle}

Ostovar, Afshon (2016). Sectarian Dilemmas in Iranian Foreign Policy. Carnegie Endowment for International Peace. A letöltés ideje: 2021. július 10. https://carnegieendowment.org/files/CEIP CP288 Ostovar Sectarianism_Final.pdf.

Ostovar, Afshon (2019). The Grand Strategy of Militant Clients: Iran's Way of War. Securily Studies, 28(1), 176-177.

Polese, Abel és Santini, Ruth H. (2018). Limited Statehood and Its Security: Implications on the Fragmentation Political Order in the Middle East and North Africa. Small Wars \& Insurgencies, 29(3), 379-390.

Posch, Walter (2013). The Third World, Global Islam and Pragmatism: The Making of Iranian Foreign Policy. Stiftung Wissenschaft und Politik. A letöltés ideje: 2021. augusztus 15. https:/www.swp-berlin.org/ publications/products/research_papers/2013 RPO3_poc.pdf.

Radio Free Europe (2020). U.S. Says Iran Continues to Smuggle 'Advanced Weapons' to Huthis in Yemen. A letöltés ideje: 2021. július 20. https:// www.rferl.org/a/us-savs-iran-continues-smuggle-weapons-huthivemen/30444599.html.

Rasa News (2015): Basij-e zharfa-ye rahbordi va eghtedar-e melli-ye Iran-e islami' [Az iszlám Irán stratégiai mélységének és nemzeti képességeinek mozgósítása]. A letöltés ideje 2021. július 10.

Riazaty, Mehran (2016). Khomeinis Warriors: Foundation of Iran's Regime, Its Guardians, Allies Around the World. Bloomington, IN: Xlibris.

Rubin, Alissa (2019). Iraqis Rise Against a Reviled Occupier: Iran. The New York Times. A letöltés ideje: 2021. augusztus 30. https://www.nytimes. com/2019/11/04/world/middleeast/ iraq-protests-iran.html.

Santini, Ruth Hanau (2017). A New Regional Cold War in the Middle East and North Africa: Regional Security Complex Theory Revisited. The International Spectator, 52(4), 93-111.

Sayigh, Yezid (2018). Hybridizing Security: Armies, Militias and Constrained Sovereignty. Carnegie Endowment for International Peace - Middle Eas/ Center. A letöltés ideje: 2021. szeptember 5. https://carnegie-mec. org/2018/10/30/hybridizing-security-armies-militias-and-constrainedsovereignty-pub-77597.

Seliktar, Ofira és Rezaei, Farhad (2020). Iran, Revolution, and Proxy Wars. New York, NY: Palgrave Macmillan.

Sluglett, Peter és Kattan, Victor (2019). Violent Radical Movements in the Arab World: The Ideology and Politics of Non-State Actors. London: I.B. Tauris. 
Soltaninejad, Mohammad (2019). Coalition-Building in Iran's Foreign Policy: Understanding the 'Axis of Resistance'. Journal of Balkan and Near Eastern Sludies, 21(6), 716-731.

Szalai Máté (2020). Az államvákuum és a hibridizáció megvalósulása Szíriában. Külügyi Szemle, 19(2), 66-86.

Tabatabai, Ariane és Clarke, Colin P. (2019). Iran's Proxies Are More Powerful Than Ever. Foreign Policy. A letöltés ideje: 2021. augusztus 15. https://foreignpolicv.com/2019/10/16/ irans-proxies-hezbollah-houthistrump-maximum-pressure/.

Tabatabai, Ariane, Martini, Jeffrey és Wasser, Becea (2019). The Iran Threat Network (ITN): Four Models of Iran's Nonstate Client Partnerships. RAND Corporation. A letöltés ideje: 2021. augusztus 30. https:/www. rand.org/content/dam/rand/pubs/research reports/RR4200/RR4231/ RAND_RR4231.pdf.

Vatanka, Alex (2018). Iran's Use of Shi'i Militant Proxies: Ideological and Practical Expediency Versus Uncertain Sustainability. Middle East Instilute. A letöltés ideje: 2021. július 30. https://www.mei.edu/sites/ default/files/publications/Vatanka_Policy Paper.pdf.

Vohra, Anchal (2021). The Axis of Resistance to Israel Is Breaking up. Foreign Policy. A letöltés ideje: 2021. augusztus 15. https://foreignpolicy. com $/ 2021 / 02 / 25 /$ the-axis-of-resistance-to-israel-is-breaking-up.

Ward, Alex (2020). The Case for Killing Qassem Soleimani: Why Trump's Decision to Target the Iranian Military Commander Was the Right Call. VOX. A letöltés ideje: 2021. július 30. https://www.vox.com/ world/2020/1/8/21055785/trump-iran-case-for-kill-qassem-soleimani.

Williams, Dan (2018). Top Israeli General Sees Increased Iran Spending on Foreign Wars. Reuters. A letöltés ideje: 2021. augusztus 15. https://www. reuters.com/article/us-iran-rallies-israel-idUSKBNIEROQ9.

Yeşiltaş, Murat és Kardaş, Tuncay (2018). Non-State Armed Aclors in the Middle East: Geopolitics, Ideology, and Strategy. Cham: Palgrave Macmillan.

Zohar, Eran (2016). A New Typology of Contemporary Armed Non-StateActors: Interpreting the Diversity. Studies in Conflict \& Terrorism, 39(5). 423-450. 